\title{
Primary headache subtypes and thyroid dysfunction: Is there any association?
}

\author{
Subtipos de cefaleia primária e disfunção tireoidiana: existe alguma associação? \\ loanna SPANOU ${ }^{1}$, Foteini CHRISTIDI', Georgios LIAKAKIS ${ }^{1}$, Konstantina RIZONAKI', Anastasia BOUGEA', \\ Evangelos ANAGNOSTOU', Evangelia KARARIZOU'
}

\begin{abstract}
Background: Primary headaches, and particularly migraine and tension-type headache (TTH) as well as hypothyroidism are common medical conditions. To date, numerous studies have suggested a possible bidirectional relationship between migraine and hypothyroidism, although certain studies had contradictory results. Objective: To investigate whether there is any association between primary headache subtypes and thyroid disorders. Methods: A retrospective study of consecutive patients aged $\geq 18$ years referred to the Headache Outpatient Clinic of Aeginition Hospital and diagnosed with primary headache and any thyroid disorder. Results: Out of 427 patients (males/ females=76/351), 253 (59.3\%) were diagnosed with migraine without aura, 53 (12.4\%) with TTH, 49 (11.5\%) with migraine with aura, 29 (6.8\%) with medication-overuse headache, 23 (5.4\%) with mixed-type headache (migraine with/without aura and TTH), nine (2.1\%) with cluster headache, and 11 (2.6\%) with other types of primary headaches. The prevalence of any type of thyroid disorder was $20.8 \%$ (89/427 patients). In the total sample, 27 patients (6.3\%) reported hypothyroidism, 18 (4.2\%) unspecified thyroidopathy, 14 (3.3\%) thyroid nodules, 12 (2.8\%) Hashimoto thyroiditis, 12 (2.8\%) thyroidectomy, three (0.7\%) thyroid goiter, and three (0.7\%) hyperthyroidism. Further statistical analysis between categorical variables did not reveal any significant association between headache subtypes and thyroid dysfunction. Conclusions: No specific association was found between primary headache subtypes and specific thyroid disorder. However, a high prevalence of thyroid dysfunction in general and specifically hypothyroidism was demonstrated among patients with primary headaches, which lays the foundation for further clarification in prospective longitudinal studies.
\end{abstract}

Keywords: Headache; Migraine Disorders; Tension-type Headache; Thyroid Diseases; Hypothyroidism.

\section{RESUMO}

Introdução: Cefaleias primárias e, particularmente, enxaqueca e cefaleia do tipo tensional (CTT), bem como hipotiroidismo, constituem condições médicas comuns. Até o momento, vários estudos sugeriram uma possível relação bidirecional entre enxaqueca e hipotireoidismo, embora alguns estudos tenham resultados contraditórios. Objetivo: Investigar se existe associação entre subtipos de cefaleia primária e distúrbios da tireoide. Métodos: Estudo retrospectivo de pacientes consecutivos com idade $\geq 18$ anos encaminhados ao Ambulatório de Cefaleia do Hospital Aeginition, com diagnóstico de cefaleia primária e qualquer distúrbio da tireoide. Resultados: De 427 pacientes (homens/mulheres=76/351), 253 pacientes (59,3\%) foram diagnosticados com enxaqueca sem aura, 53 (12,4\%) com CTT, 49 (11,5\%) com enxaqueca com aura, 29 (6,8 \%) com cefaleia por uso excessivo de medicamentos, 23 (5,4\%) com cefaleia mista (enxaqueca com/sem aura e CTT), nove (2,1\%) com cefaleia em salvas e 11 (2,6\%) com outros tipos de cefaleias primárias. A prevalência de qualquer tipo de distúrbio tireoidiano foi de 20,8\% (89/427 pacientes). Na amostra total, 27 pacientes (6,3\%) relataram hipotireoidismo, 18 (4,2\%) tireoidopatia não especificada, 14 (3,3\%) nódulos de tireoide, 12 (2,8\%) tireoidite de Hashimoto, 12 (2,8\%) tireoidectomia, três (0,7\%) bócio da tireoide e três $(0,7 \%)$ hipertireoidismo. Uma análise estatística posterior entre as variáveis categóricas não revelou qualquer associação significativa entre os subtipos de cefaleia e disfunção tireoidiana. Conclusões: Não encontramos associação entre subtipos de cefaleia primária e distúrbio específico da tireoide. No entanto, foi observada prevalência elevada de disfunção tireoidiana em geral e especificamente hipotireoidismo entre pacientes com cefaleia primária, o que estabelece base para maiores esclarecimentos em estudos longitudinais prospectivos.

Palavras-chave: Cefaleia Primária; Transtornos de Enxaqueca; Cefaleia de Tipo Tensional; Distúrbio da Tireoide; Hipotireoidismo.

\footnotetext{
'National and Kapodistrian University of Athens, Medical School, Aeginition Hospital, Athens, Greece.

Ioanna SPANOU (D) https://orcid.org/0000-0002-1743-9648; Foteini CHRISTIDI (D) https://orcid.org/0000-0003-1297-9415; Georgios LIAKAKIS (DD https:// orcid.org/0000-0002-7024-3070; Konstantina RIZONAKI (D) https://orcid.org/0000-0003-1585-4685; Anastasia BOUGEA (D) https://orcid.org/0000-00033006-8711; Evangelos ANAGNOSTOU (D) https://orcid.org/ 0000-0002-9579-8136; Evangelia KARARIZOU (D) https://orcid.org/0000-000336164552

Correspondence: loanna Spanou; E-mail: ionspanou85@yahoo.gr

Conflict of interest: There is no conflict of interest to declare.

Authors' contributions: IS and EK: conception and design. IS, GL, KR and AB: acquisition of data. IS, FC and EK: analysis and interpretation of data. IS and EK: drafting the manuscript. IS, FC, GL, KR, AB, EA and EK: revising it for intellectual content and final approval of the completed manuscript.

Disclosure: An earlier version of this work has been presented as an abstract at the $13^{\text {th }}$ European Headache Federation Congress.

Received on February 12, 2020; Received in its final form on May 3, 2020; Accepted on May 17, 2020.
} 


\section{INTRODUCTION}

Primary headaches are very common medical conditions worldwide and have a significant deleterious effect on public health. Particularly, almost three billion individuals were estimated to have migraine or tension-type headache (TTH) in $2016^{1}$, with migraine being the third most prevalent disorder in the world ${ }^{1}$ and the first cause of disability in individuals under the age of $50^{2}$. Migraine is associated with a variety of comorbidities, including the endocrine system (endometriosis and polycystic ovary syndrome), determining disease progression and therapeutic strategies ${ }^{3}$.

Hypothyroidism is also a very common condition, with the prevalence of clinical hypothyroidism in the general population in Europe being between 0.2 and 5.3\% Hypothyroidism is characterized by thyroid hormone deficiency and influences nearly all major organs, including the central nervous system ${ }^{6}$. Headache is one of the most common symptoms of hypothyroidism, affecting approximately one-third of the patients?

Over the previous two decades, numerous studies have investigated the association between migraine and hypothyroidism ${ }^{3}$. In our recent review investigating the relationship between primary headaches (migraine and TTH) and hypothyroidism ${ }^{8}$, the existing data were inadequate to answer with certainty about their relationship. However, suggestions for a possible bidirectional association could exist.

To that direction, the objective of our study was to investigate if there was any association between primary headache subtypes and thyroid dysfunction for the first time in a Greek population.

\section{METHODS}

\section{Study sample}

A retrospective study was conducted on the clinical records (both written and electronic database) of 490 consecutive patients referred to the Headache Outpatient Clinic of Aeginition Hospital from January $1^{\text {st }}, 2010$ to December $31^{\text {st }}$, 2018 and diagnosed with a primary headache. The final sample included 427 patients, having been formed after exclusion of nine patients aged less than 18 years, 37 patients with missing clinical data, 17 patients with a comorbid neurologic disease (epilepsy; stroke; traumatic brain injury; brain tumor; multiple sclerosis; myopathy). Primary headache diagnoses were based on the criteria of the International Classification of Headache Disorders, third edition beta version? ${ }^{7}$. The study was approved by the Ethics Committee of Aeginition Hospital and all patients participating in the study signed an informed consent form.

Thyroid dysfunction was assessed based on the available data on records mostly related to patients' self-reports during the interview, and only a minority of the cases was demonstrated by provided hormonal measurements (in 10 out of 427 patients/2.3\%). Demographic (age, sex) and clinical data were recorded for all patients. Clinical data included the primary headache subtype, the presence of thyroid disorder and its specific type, and previous medical history and medication intake.

\section{Statistical analysis}

All data were analyzed using the Statistical Package for the Social Sciences (SPSS v. 22). Continuous variables are presented as mean and standard deviation (SD) while categorical variables are presented as absolute values and percentage. Comparisons between categorical variables were conducted using $\chi^{2}$ (chi-square test) in order to evaluate any association between thyroid dysfunction and headache. The level of statistical significance was set at $\mathrm{p}<0.05$.

\section{RESULTS}

Out of 427 patients (males/females=76/351), 253 patients (59.3\%) met the diagnostic criteria for migraine without aura (MwoA) and 49 (11.5\%) for migraine with aura (MwA). 53 patients (12.4\%) suffered from TTH and 23 (5.4\%) from mixed-type headache (MwoA or MwA and TTH). Additionally, 29 patients (6.8\%) were diagnosed with medication-overuse headache $(\mathrm{MOH})$, nine $(2.1 \%)$ with cluster headache $(\mathrm{CH})$, and $11(2.6 \%)$ with other types of primary headaches (mainly trigeminal neuralgia).

The prevalence of any type of thyroid disorder was $20.8 \%$ (89/427 patients). In the total sample, 27 patients $(6.3 \%)$ reported hypothyroidism, 18 (4.2\%) unspecified thyroidopathy, 14 (3.3\%) thyroid nodules, 12 (2.8\%) Hashimoto thyroiditis, $12(2.8 \%)$ thyroidectomy, three (0.7\%) thyroid goiter, and three $(0.7 \%)$ hyperthyroidism (Figure 1$)$. Among patients with thyroidectomy, nobody reported medical history of thyroid cancer. However, further statistical analysis between categorical variables $\left(\chi^{2}\right)$ did not reveal any significant association between headache subtypes and thyroid dysfunction $\left(\chi^{2}=40.112 ; \mathrm{p}=0.254, \mathrm{~ns}\right)$. Table 1 presents the distribution of different types of thyroid dysfunction across the different headache groups.

\section{DISCUSSION}

The results of the present study, concerning our primary question, did not demonstrate any significant association between primary headache subtypes and thyroid dysfunction. Nevertheless, we found a high prevalence of thyroid dysfunction in general (20.7\%) and specifically hypothyroidism (6.3\%) among our patients with primary headaches. 
10

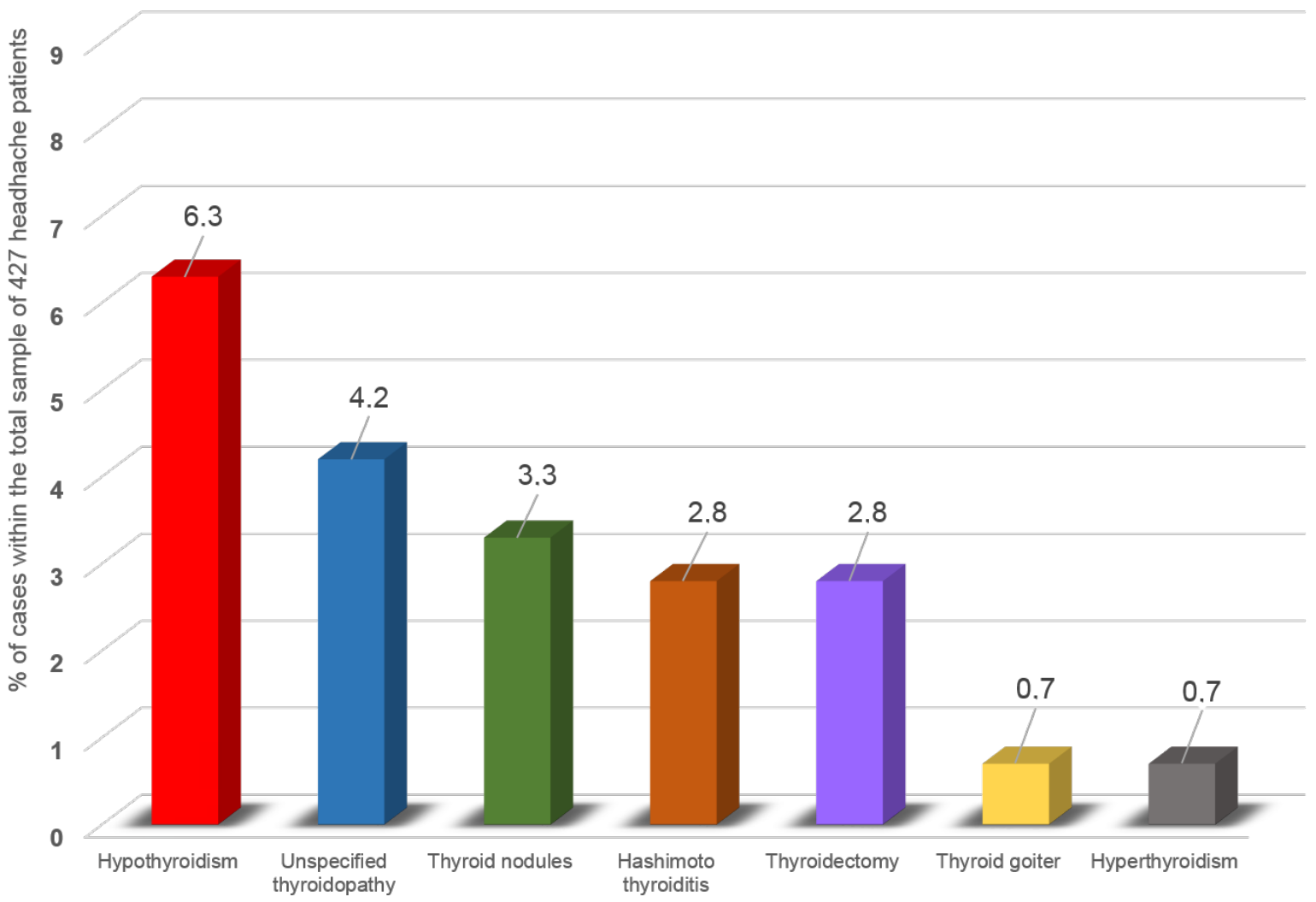

Figure 1. Percentage of patients with different types of thyroid dysfunctions within the total sample of 427 headache patients.

Table 1. Distribution of different types of thyroid dysfunction across the headache groups in the total sample of 427 headache patients.

\begin{tabular}{|c|c|c|c|c|c|c|c|c|}
\hline & & $\begin{array}{l}\text { Migraine w/ } \\
\text { wo aura }\end{array}$ & $\begin{array}{l}\text { Tension-type } \\
\text { headache }\end{array}$ & $\begin{array}{c}\text { Medication- } \\
\text { overused headache }\end{array}$ & $\begin{array}{c}\text { Cluster } \\
\text { headache }\end{array}$ & $\begin{array}{l}\text { Mixed-type } \\
\text { headache }\end{array}$ & $\begin{array}{l}\text { Other primary } \\
\text { headache }\end{array}$ & Total \\
\hline \multirow{2}{*}{ Normal thyroid } & $n$ & 246 & 40 & 19 & 8 & 15 & 10 & 338 \\
\hline & $\%$ & 57.6 & 9.4 & 4.5 & 1.9 & 3.5 & 2.3 & 79.2 \\
\hline \multirow{2}{*}{ Hypothyroidism } & $\mathrm{n}$ & 17 & 5 & 2 & 0 & 3 & 0 & 27 \\
\hline & $\%$ & 4.0 & 1.2 & 0.5 & 0 & 0.7 & 0 & 6.3 \\
\hline \multirow{2}{*}{$\begin{array}{l}\text { Unspecified } \\
\text { thyroidopathy }\end{array}$} & $n$ & 13 & 3 & 1 & 0 & 0 & 1 & 18 \\
\hline & $\%$ & 3.0 & 0.7 & 0.2 & 0 & 0 & 0.2 & 4.2 \\
\hline \multirow{2}{*}{ Thyroid nodules } & $n$ & 8 & 3 & 2 & 0 & 1 & 0 & 14 \\
\hline & $\%$ & 1.9 & 0.7 & 0.5 & 0 & 0.2 & 0 & 3.3 \\
\hline \multirow{2}{*}{$\begin{array}{l}\text { Hashimoto } \\
\text { thyroiditis }\end{array}$} & $n$ & 7 & 1 & 2 & 0 & 2 & 0 & 12 \\
\hline & $\%$ & 1.6 & 0.2 & 0.5 & 0 & 0.5 & 0 & 2.8 \\
\hline \multirow{2}{*}{ Thyroidectomy } & $n$ & 6 & 1 & 2 & 1 & 2 & 0 & 12 \\
\hline & $\%$ & 1.4 & 0.2 & 0.5 & 0.2 & 0.5 & 0 & 2.8 \\
\hline \multirow{2}{*}{ Thyroid goiter } & $n$ & 3 & 0 & 0 & 0 & 0 & 0 & 3 \\
\hline & $\%$ & 0.7 & 0 & 0 & 0 & 0 & 0 & 0.7 \\
\hline \multirow{2}{*}{ Hyperthyroidism } & $n$ & 1 & 0 & 1 & 0 & 0 & 1 & 3 \\
\hline & $\%$ & 0.2 & 0 & 0.2 & 0 & 0 & 0.2 & 0.7 \\
\hline \multirow{2}{*}{ Total } & $n$ & 301 & 53 & 29 & 9 & 23 & 12 & 427 \\
\hline & $\%$ & 70.5 & 12.4 & 6.8 & 2.1 & 5.4 & 2.8 & 100.0 \\
\hline
\end{tabular}

The $\%$ of cases was calculated based on the total sample of 427 headache patients. 
From the literature search, several studies investigated a possible comorbidity between migraine and hypothyroidism. Comorbidity in general, refers to the greater than coincidental association of separate conditions ${ }^{9}$. Positive outcomes on the aforementioned hypothesis were demonstrated in three studies ${ }^{10,11,12}$. In particular, the study by Rubino et al. ${ }^{10}$ reported a high prevalence of migraine in patients with subclinical hypothyroidism compared to controls ( $46 \%$ versus $13 \%$, respectively). Additionally, Tietjen et al. ${ }^{11}$, in a retrospective cohort of consecutive migraine patients, investigating the presence of distinguishable migraine comorbidities, described a subgroup with a high incidence of metabolic comorbidities (hypertension, hyperlipidemia, diabetes mellitus) and hypothyroidism. Also, Le et al. ${ }^{12}$, in a large Danish population-based study of 31,865 twins, found a prevalence of migraine in 8,044 of them, and comorbidity with any thyroid disease in 562/8,044 (7\%) of them. Interestingly, in 2001, the study of Hagen et al. ${ }^{13}$, presented contradictory findings. More specifically, they demonstrated a low prevalence of headache (migraine and non-migraine) in adults with high thyroid stimulating hormone (TSH), while on the other hand, described a particular group of individuals with a known history of hypothyroidism in whom the prevalence of headache was higher. Recently, a Russian study ${ }^{14}$ reported negative results regarding migraine comorbidity with thyroid dysfunction, as abnormal TSH levels (either lower or higher than normal) found only in $5 \%$ of the migraineurs studied. However, this study found that lower TSH values (even in terms of its normal values) were associated with more prolonged migraine attacks and with a greater impact on quality of life, with the investigators suggesting that thyrotropin levels should be verified in patients with severe migraine, with appropriate correction if needed.

Unfortunately, due to the retrospective design of this study, which constitutes its major limitation, there is a lack of information about any possible temporal association between the onset of hypothyroidism and headache, thus it was not possible to assume any cases of headache attributed to hypothyroidism (HAH). Concerning the definition of $\mathrm{HAH}$, Moreau et al..$^{15}$ define it as a headache which generally begins two months after the onset of hypothyroidism, while Lima Carvalho et al. ${ }^{16}$ identify it as a new headache disorder starting in close relationship with the other symptoms of hypothyroidism or a worsening of a previous primary headache in a temporal relationship with hypothyroidism onset. HAH describes a headache that improves or disappears after hormonal replacement therapy during a three-month ${ }^{16}$ to one-year ${ }^{15}$ follow-up. Thus, from the aforementioned, investigating for hypothyroidism in a patient with headache is necessary, as by correcting this endocrinological disorder patients' headaches might improve.

Additionally, in a randomized case-control study, Bigal et al. ${ }^{17}$ investigated the factors related to the transformation from episodic to chronic migraine. Among them, hypothyroidism has been demonstrated to contribute to migraine chronification.

Furthermore, again due to the retrospective nature of our study, we could not investigate whether primary headaches may increase the risk of future development of hypothyroidism. In the literature, only one study has been published investigating the aforementioned hypothesis. In particular, Martin et al. ${ }^{18}$, in a retrospective cohort of 8,412 adults during a long follow-up period, headaches were present in about $26 \%$ of participants while new-onset hypothyroidism developed in $8.2 \%$ of those with a preexisting headache history and in $10.8 \%$ of those with a previous history of migraine.

Regarding the other subtypes of primary headaches, only one study about chronic $\mathrm{TTH}^{19}$ has been published and demonstrated that the hypothalamus-pituitary-thyroid axis is hypoactive during a headache attack.

The present study has some limitations. As already mentioned, the retrospective nature of chart review comprises a significant limitation. Additionally, the results observed in the study were limited due to the fact that the diagnosis of thyroid disorders was based mainly on patients' selfreports, which may have increased the likelihood of finding an association with thyroid dysfunction and primary headaches in general. Also, our study population is not representative of the general population, as patients who refer to a specialized headache center tend to have more severe, atypical or difficult-to-treat symptoms. Thus, a selection bias cannot be excluded.

In conclusion, it was not possible to find any specific association between primary headache subtypes and specific thyroid disorder in the present study. However, a high prevalence of thyroid dysfunction in general and specifically hypothyroidism was demonstrated among patients with primary headaches. Thus, the findings presented here lay the foundation for further clarification in prospective longitudinal studies and highlight the importance of a multidisciplinary approach that might have significant clinical implications for the treatment of patients.

\section{References}

1. GBD 2016 Neurology Collaborators. Global, regional, and national burden of neurological disorders, 1990-2016: a systematic analysis for the Global Burden of Disease Study 2016. Lancet Neurol. 2019 May;18(5):459-80. https://doi.org/10.1016/S1474-4422(18)30499-X
2. Steiner T, Stovner L, Vos T, Jensen R, Katsarava Z. Migraine is first cause of disability in under 50s: will health politicians now take notice? J Headache Pain. 2018;19(1):17. https://doi.org/10.1186/ s10194-018-0846-2 
3. Rainero I, Govone F, Gai A, Vacca A, Rubino E. Is migraine primarily a metaboloendocrine disorder? Curr Pain Headache Rep. 2018 Apr;22(5):36. https://doi.org/10.1007/s11916-0180691-7

4. Asvold BO, Vatten LJ, Bjoro T. Changes in the prevalence of hypothyroidism: the HUNT Study in Norway. Eur J Endocrinol. 2013 Oct;169(5):613-20. https://doi.org/10.1530/EJE-13-0459

5. Garmendia Madariaga A, Santos Palacios S, Guillén-Grima F, Galofré $J C$. The incidence and prevalence of thyroid dysfunction in Europe: a meta-analysis. J Clin Endocrinol Metab. 2014 Mar;99(3):923-31. https://doi.org/10.1210/jc.2013-2409

6. Aoki Y, Belin RM, Clickner R, Jeffries R, Phillips L, Mahaffey KR. Serum TSH and total T4 in the United States population and their association with participant characteristics: National Health and Nutrition Examination Survey (NHANES 1999-2002). Thyroid. 2007 Dec;17(12):1211-23. https://doi.org/10.1089/ thy. 2006.0235

7. Headache Classification Committee of the International Headache Society (IHS). The International Classification of Headache Disorders, 3rd edition (beta version). Cephalalgia. 2013 Jul;33(9):629-808. https://doi. org/10.1177/0333102413485658

8. Spanou I, Bougea A, Liakakis G, Rizonaki K, Anagnostou E, Duntas $L$, et al. Relationship of migraine and tension-type headache with hypothyroidism: a literature review. Headache. 2019 Sep;59(8):117486. https://doi.org/10.1111/head.13600

9. Feinstein AR. THE PRE-THERAPEUTIC CLASSIFICATION OF COMORBIDITY IN CHRONIC DISEASE.J Chronic Dis. 1970 Dec;23(7):45568. https://doi.org/10.1016/0021-9681(70)90054-8

10. Rubino E, Rainero I, Garino F, Vicentini C, Govone F, Vacca A, et al. Subclinical hypothyroidism is associated with migraine: A casecontrol study. Cephalalgia. 2019 Jan;39(1):15-20. https://doi. org/10.1177/0333102418769917
11. Tietjen GE, Herial NA, Hardgrove J, Utley C, White L. Migraine comorbidity constellations. Headache. 2007 Jun;47(6):857-65. https://doi.org/10.1111/j.1526-4610.2007.00814.x

12. Le H, Tfelt-Hansen P, Russell MB, Skytthe A, Kyvik KO, Olesen J. Co-morbidity of migraine with somatic disease in a large populationbased study. Cephalalgia. 2010 Jun;31(1):43-64. https://doi. org/10.1177/0333102410373159

13. Hagen K, Bjoro T, Zwart JA, Vatten L, Stovner LJ, Bovim G. Low headache prevalence amongst women with high TSH values. Eur J Neurol. 2001;8(6):693-9. https://doi.org/10.1046/j.1468-1331.2001.00310.x

14. Starikova NL, Baidina TV, Kalashnikova TP. Thyrotropin levels and severity of symptoms in migraine patients of tertiary headache center. Cephalalgia. 2019 Jan;39(1):148-52. https://doi. org/10.1177/0333102418794941

15. Moreau T, Manceau E, Giroud-Baleydier F, Dumas R, Giroud M. Headache in hypothyroidism. Prevalence and outcome under thyroid hormone therapy. Cephalalgia. 1998 Dec;18(10):687-9. https://doi. org/10.1046/j.1468-2982.1998.1810687.x

16. Lima Carvalho MF, de Medeiros JS, Valença MM. Headache in recent onset hypothyroidism: Prevalence, characteristics and outcome after treatment with levothyroxine. Cephalalgia. 2017 Sep;37(10):938-46. https://doi.org/10.1177/0333102416658714

17. Bigal ME, Sheftell FD, Rapoport AM, Tepper SJ, Lipton RB. Chronic daily headache: identification of factors associated with induction and transformation. Headache. Jul-Aug 2002;42(7):575-81. https:// doi.org/10.1046/j.1526-4610.2002.02143.x

18. Martin AT, Pinney SM, Xie C, Herrick RL, Bai Y, Buckholz J, et al. Headache disorders may be a risk factor for the development of new onset hypothyroidism. Headache. 2017 Jan;57(1):21-30. https://doi. org/10.1111/head.12943

19. Qu P, Yu JX, Xia L, Chen GH. Cognitive performance and the alteration of neuroendocrine hormones in chronic tension-type headache. Pain Pract. 2018 Jan;18(1):8-17. https://doi.org/10.1111/papr.12574 